\title{
Geoarchaeology: Egyptian Predynastic Ceramics and Geochemistry
}

\author{
by Hany Hamroush
}

Geological techniques are increasingly being used in reconstructing the archaeological development and evolution of early societies. This article discusses the application of geochemistry to the correlation of recent sediments along the Nile River at Hierakonpolis, one of the key archaeological sites in the study of the origins of the Pharaonic civilization. The author also shows how geochemical analyses are assisting in understanding the early manufacture of Egyptian ceramics. (Ed.)

\section{Introduction: The Rise of the Pharoahs}

Five thousand years ago, the ancient Egyptians were laying down the foundations for the first nation state. Scholars from many countries, beginning with the Greek historian Herodotus (484-425 BC) have wondered about the role of the Nile and its sediment load in the origin and development of the impressive Pharaonic civilization along its banks. This Dynastic civilization has never ceased to fascinate scientists from all over the world and, indecd, anyone who comes in contact with its manifestations, but its origins are still not fully understood (Hassan, 1980).

The period of food-producing communities immediately preceding the unification of Lower and Upper Egypt and the emergence of Dynastic (Pharaonic) Egypt may be referred to as the Predynastic period. This spans approximately two thousand years, from $5000 \mathrm{BC}$ to $3200 \mathrm{BC}$. Part of the challenge in understanding this period comes from the difficulty of deciphering the environmental conditions and the processes that affected the Predynastic settlements in the Nile flood plain.

An archaeological site such as Hierakonpolis (Fig. 1 ) is an excellent place for a geochemical approach to this problem. Its fascinating links to the first pharaoh was recognized by the ancient Egyptians themselves, and more than 80 years of archaeological research has now confirmed the central role of Hierakonpolis in the transition from the Predynastic to Dynastic period and in the rise of the early Egyptian civilization (Hoffman, 1982). 'The name "Hierakonpolis" was initially used to refer to the ancient royal walled town of Nekhen, locally known as Kom el Ahmar. It was a place of religious and political distinction, and was probably the capital of the Predynastic kingdom of Upper Egypt.

\section{The Use of Geoarchaeology}

Geoarchaeology is the application of the earth sciences, particularly stratigraphy, geochemistry, geomorphology, and sedimentology to the interpretation and environmental reconstruction of archaeological sites. It involves evaluating the landscape to assist in locating archaeological sites

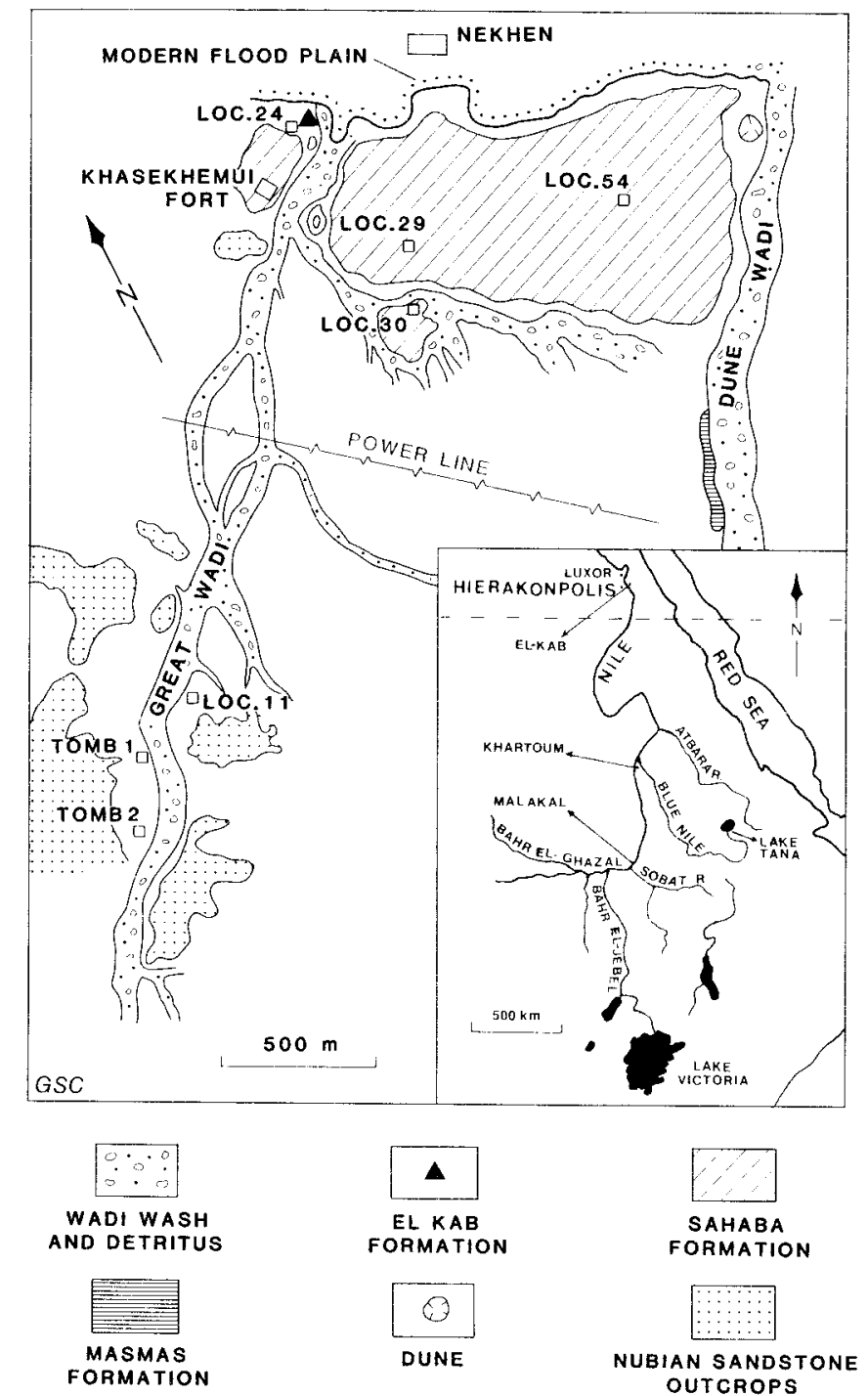

Figure 1: Map of Hierakonpolis showing the locations of some of the Predynastic sites and the general geology of the area. The units above the Nubian sandstone are upper pleistocene and younger. The Nile River is $3 \mathrm{~km}$ to the north. 
and site catchment activities (Gladfelter, 1977), regional stratigraphic and microstratigraphic studies for relative dating (e.g. Butzer and Hansen, 1968), paleoenvironmental analysis (Hassan, 1978, and Butzer, 1971), and mineralogical and chemical studies of artifacts to determine manufacturing practices, trade and exchange networks (e.g. Allen et al., 1984).

Modern archaeologists regard such studies as important tools for analysing their sites. Thus, recent expeditions to Egypt have paid attention to the relationship between geological setting of a region and settlement location and to the nature of site-forming processes. However, there have been difficulties in correlating and identifying Nilotic units by conventional geological approaches (Wendorf and Schild, 1976, Hamroush, 1982). Geochemical techniques have now been found useful in characterizing different types of river sediments such as those of the river Nile. They have also assisted in understanding and monitoring technological changes in the production of ceramic artifacts.

Pottery manufacture during the Predynastic period is traditionally subdivided into archaeological units, often referred to as "cultures," on the basis of their ceramic content (Hoffman, 1979). However, there is no scientific explanation of how technology ehanged over time to produce different ceramies. In particular, the abrupt change in style between the Predynastic and early Dynastic periods remains a puzzle.

\section{Stratigraphy of Nile Sediments}

The interpretation of the stratigraphy at Prehistoric sites along the Nile has been difficult, especially when trying to correlate markedly similar river sediments. The oldest exposed rocks at Hierakonpolis (Fig. 1) belong to the upper part of the Cretaceous Nubia Formation, which contains variegated shale and ferruginous sandstone and which extends into the desert west of the present cultivation zone. These older sedimentary deposits are covered by Nile sediments of Pleistocene age. The major Predynastic habitation sites are located between two large wadis that dissect Upper Pleistocene Nile silts, such as those of the Masmas and Sahaba formations.

More than six geological units have been identified within these sediments (Butzer, 1960; Hassan, personal communication, and Hamroush, 1982). The Masmas, Sahaba and El-Kab formations are of geoarchaeological importance because Predynastic remains such as ceramic sherds, lithic artifacts, and bones (Fig. 2) are found on their upper surfaces, and because they represent a potential source of raw materials that could have been used by Predynastic people for manufacturing different types of ceramics.

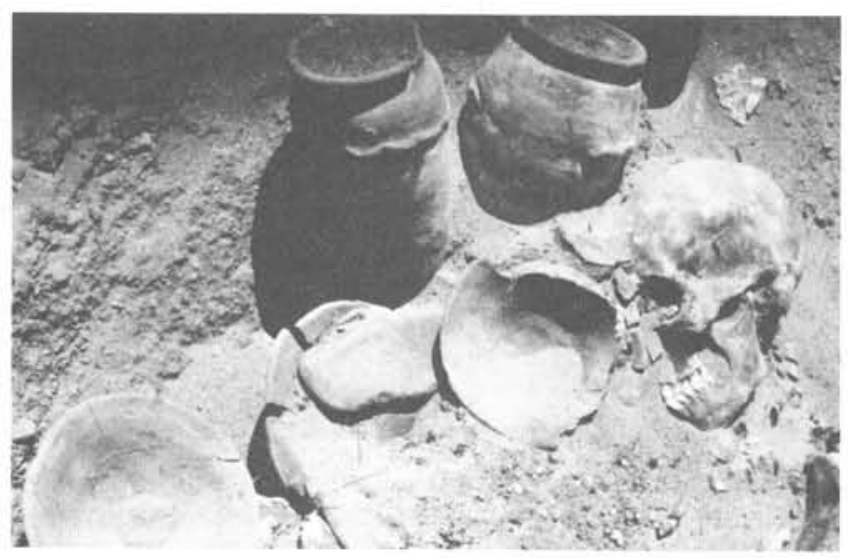

Figure 2: Late Predynastic grave at Hierakonpolis.

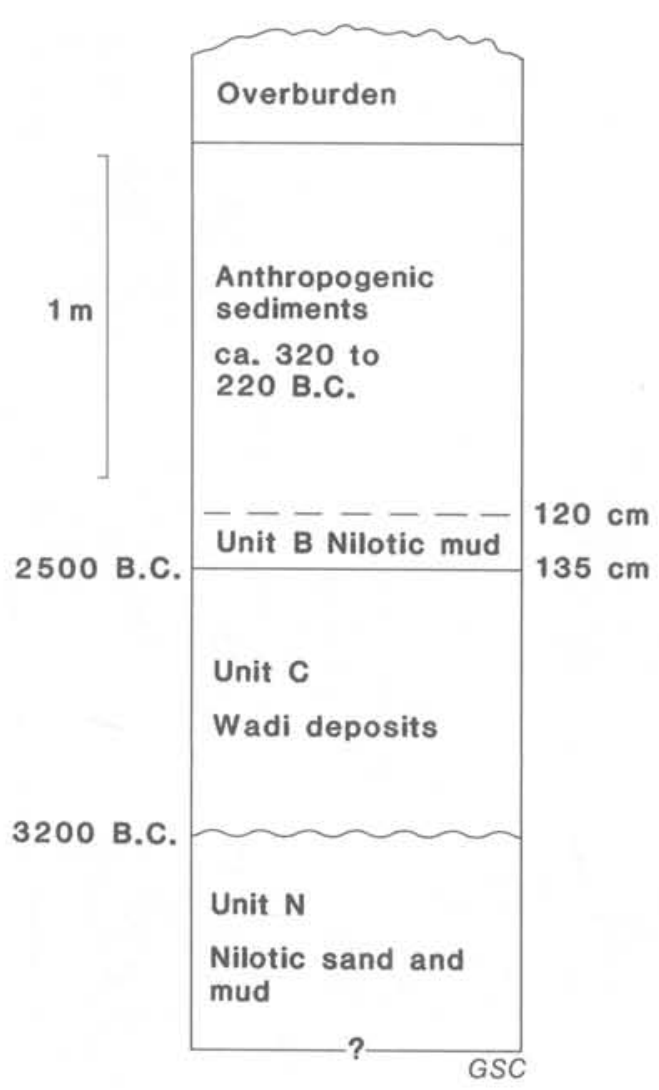

Figure 3: Stratigraphic units at Nekhen. Wavy line indicates gradational contact.

The term "Masmas Formation" was introduced by Butzer and Hansen in 1968 for Nilotic sediments of clayey silt and sandy silt on the Kom Ombo plain south of Hierakonpolis (see also Issawi, 1983). These represent the oldest Late Pleistocene Nile silt unit at Hierakonpolis, and have yielded a radiocarbon date of ca. 13,330 BC. They were deposited over an extensive plain by summer floods analogous to those of today. The sediments are exposed along the Dune Wadi and also have been recovered at locality 11 (Fig. 1) as a result of archaeological excavations during the field season of 1978 (Hamroush, 1982).

The Sahaba Formation (de Heinzelin, 1968) comprises massive Nilotic silts and fine-grained micaceous sand at the Sahaba district in Sudanese Nubia. Archaeological materials and radiocarbon dates give the age of this unit between 15,000 and 12,000 yBP (Said, 1981). At Hierakonpolis, the Sahaba silts cover an extensive area in which Predynastic sites (e.g. loes. 29, 30 and 54) bordering the modern flood plain are located.

Massive silts and clays younger than those of the Sahaba Formation in an area now mostly under cultivation at the El-Kab site east of Hierakonpolis, make up the "El-Kab lithozone," first introduced by Vermeersch (1970). At El-Kab, three radiocarbon dates on charcoal (6400, 6040 and $5980 \mathrm{BC}$ ) have been assigned to this unit. At Hierakonpolis, El-Kab Nile silt is found only at one site bordering the cultivated area (locality 24). Because of the intensive use of the modern flood plain at Hierakonpolis, little was known until recently about the nature and the distribution of the geological sediments around Nekhen.

In 1984, detailed geological studies of the cores and trenches dug under the modern cultivation zone at Nekhen indicated the presence of three lithological units (Fig. 3). Unit B is a clayey silt of Nilotic origin that is closely associated with various types of ceramic sherds. It is 


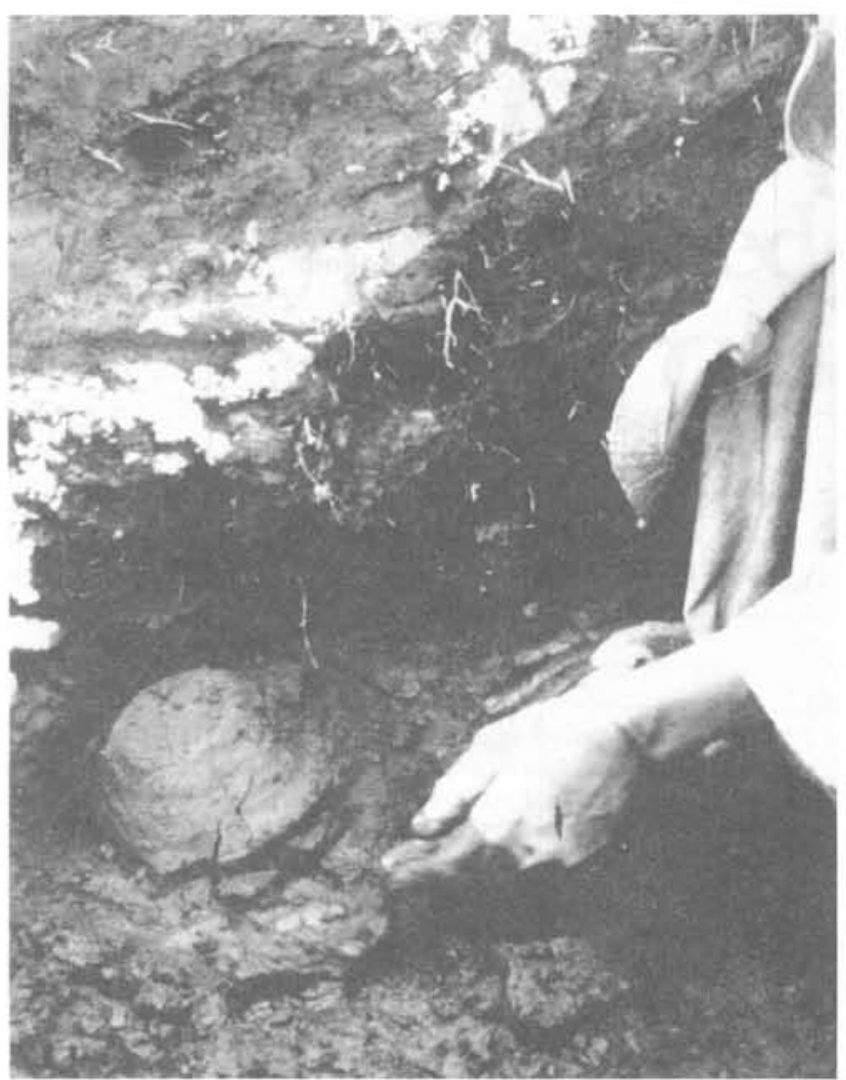

Figure 4: Uncovering a ceramic pot from near the boundary between units $N$ and $C$ at Nekhen.

considered to belong to the modern river alluvium, dating from around $2500 \mathrm{BC}$ to about $230 \mathrm{BC}$. Unit C is a silty sand with occasional gravels that are poorly sorted. It is associated with various types of Predynastic artifacts and regarded as local in origin. At its base is unit $\mathrm{N}$, a very compact, well sorted Nile mud, older than $3200 \mathrm{BC}$, with occasional Predynastic ceramies and lithic artifacts (Fig. 4).

At some sites the sequence of these Nile sediments may differ, and some units may be absent. However, the geological characteristies of unit $\mathrm{N}$ and its position 76.5 to 80 $\mathrm{m}$ above sea level suggest that it corresponds to the Nekheb lithozone across the Nile at the El-Kab site, also at 78.5 to $80 \mathrm{~m}$ above sea level. A deposit similar to unit $\mathrm{C}$ of sand and gravels of local origin has also been identified at El-Kab, where it is called the "Beit Shared lithozone." These deposits are important in establishing the environmental conditions that existed just before and during the occupation of these important archaeological sites during Predynastic times. However, it was apparent that another method to distinguish and relate various Nile deposits would greatly enhance our stratigraphic approaches at these two sites.

\section{Sediment Geochemistry at Hierakonpolis}

The Nilotic sediments of Upper Egypt were originally derived from rocks upstream in two different basins in the Nile drainage area (Shukri, 1950, 1951; Kholief et al., 1969; Hassan, 1976a, 1976b). These are the Ethiopian (Abyssinian) and the Central African basins. The former consists of two major rivers, the Atbara, which drains the eastern areas of the Abyssinian Plateau, and the Blue Nile, which starts at Lake Tana and receives its discharge from a widespread area in the Ethiopian Plateau (Fig. 1). This area is composed mainly of Tertiary to Recent voleanies (e.g. trachytes, basalts and pyroclastics), all originating from voleanic centers in the East African Rift (Baker et al., 1975).
The Central African Basin consists of three major rivers, the Sobat, the Bahr el-Ghazal, and the Bahr el-Gebel. These meet south of Malakal to enter the White Nile system about $800 \mathrm{~km}$ upstream from the Blue Nile (Fig. 1). The rocks of this basin are mainly metamorphic and igneous (e.g. granites, phyllites and quartzite; Stheeman, 1932).

Many studies have indicated that the equatorial and East African lands have undergone several dramatic climatic changes during the Pleistocene period (Cerling et al., 1977a, 1977b; Nilsson, 1983; Petit-Maire, 1986). During Neolithic times (ca. 6000-5000 yBP), the climate in the Ethiopian Plateau was considerably wetter than it is today. At the end of this period, about four or five thousand years ago, a major climatic change occurred throughout Africa and conditions began to approach those of today. The past two millenia have been relatively stable in terms of elimate, with fluctuations in this period small in comparison with those of the Pleistocene and early Holocene (Nicholson, 1980).

Predynastic settlements seem to have been established in many places along the Nile Valley on promontories of abandoned Late Pleistocene terraces overlooking the flood plain of the Nile and on the outer margins of the floodplain itself, as in the case of Nekhen. Such locations would have been advantageous, for they would have provided both protection from high floods and ready access to Nile and desert resources.

Climatic conditions in various parts of the Nile basin were presumably influential in determining water discharge and the relative contributions of the sediment load from the two sources. These fluctuations should ultimately be reflected in differences in trace element distributions in Nilotic sediments. The problem is that in Upper Egypt these sediments are mainly composed of clay minerals, formed by the chemical alteration of igneous and metamorphic minerals in the rocks within the drainage basins. The sediment forming processes, including the formation of clay minerals in the Nilotic sediments, ean cause homogenization of trace element distributions in the bulk samples. On the other hand, the mineral fragements present in the sand-sized fraction of the Nilotic sediments have not been altered to clay minerals, and their trace element distributions should reflect that of the source rocks.

The chemical results show that Unit $\mathrm{C}$ ean be clearly differentiated from Units $\mathrm{N}$ and B. Samples of unit $\mathrm{N}$ also clearly correspond in chemistry to those of the Nekheb lithozone found at the El-Kab site across the Nile, as discussed earlier.

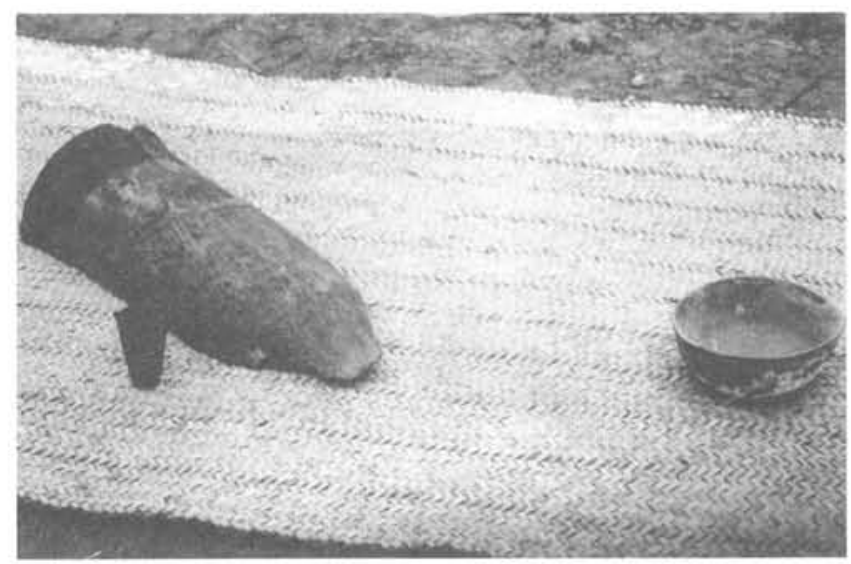

Figure 5: Ceramic artifacts recovered from excavations at Hierakonpolis. On the left, a fragment of a plum red ware ceramic jar with a black top, and on the right a ceramic dish. 


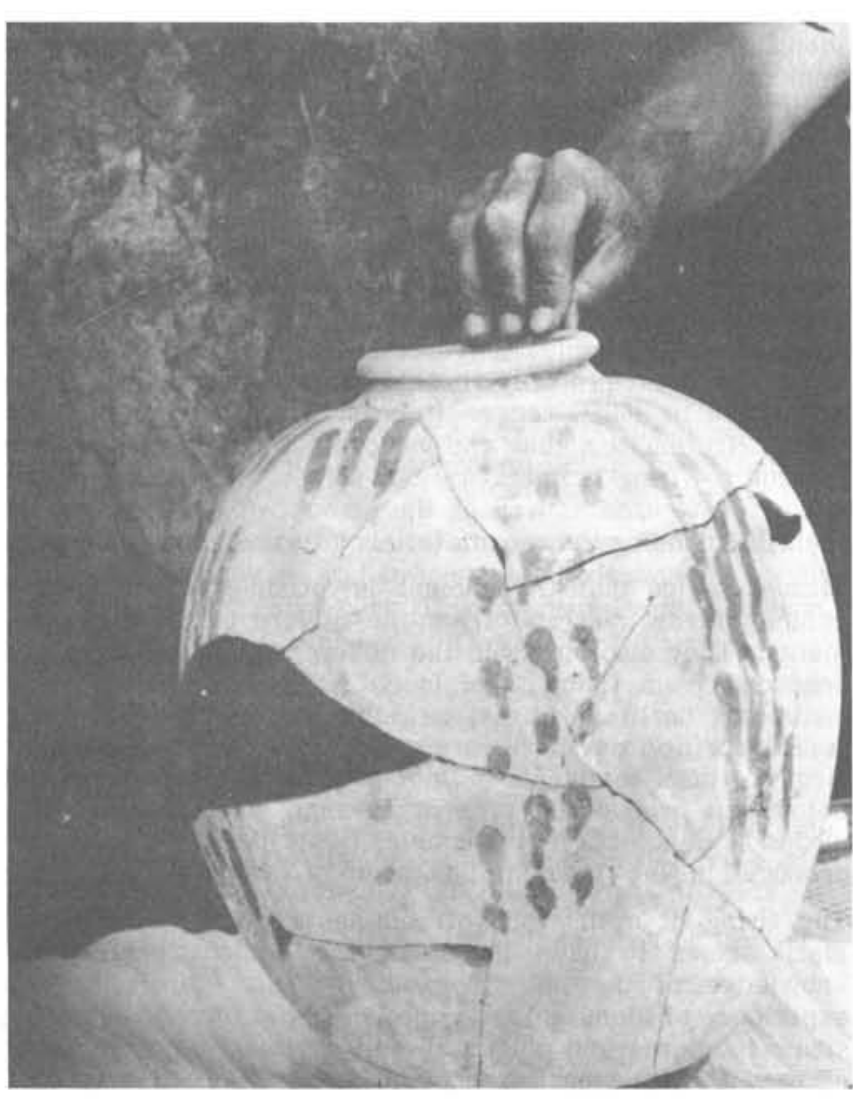

Figure 6: A reconstructed Gerzean (3700-3200 BC) marl-ware jar with blue decorations.

The study of units $\mathrm{N}$ and $\mathrm{C}$ at Hierakonpolis also provides some clues as to the climatic conditions and the changes in the Nile regime during the Predynastic and early Dynastic periods. The composition and elevation of Unit $\mathrm{N}$ indicates that during the Predynastic period, the high floods reached an elevation of at least $80 \mathrm{~m}$ above sea level at Hierakonpolis. This seems relatively low when compared with the high Nile floods of the Masmas Formation which here reached $98 \mathrm{~m}$ above sea level.

The lack of any wadi sediments intercalated with the sediments of Unit $\mathrm{N}$ suggests that during its deposition the wadis were not as active as they were at several time intervals during the earlier Pleistocene. In fact, there were no streams of any significance except in major wadis such as Wadi Qena and Wade Hammamat on the east bank of the Nile to the north, and even these were basically ephemeral streams dominated by erosion rather than deposition (Hassan, 1980; Issawi, 1983). At the end of this period, around $3100 \mathrm{BC}$, the level of the Nile floods apparently diminished, because the next sediment deposits in the Nekhen area (Unit C) are from a completely different source. These were deposited during a period (3200-2500 $\mathrm{BC})$ of relatively wet climate.

\section{Evolution of Predynastic Ceramic Technology}

The activities of the ancient Egyptians during the Predynastic period included not only cultivation, hunting and gathering, but also the manufacture of ceramics, relicts of which are the primary components of Predynastic sites. Today, Nekhen is known to the local villagers as the "Red Dome," because of the countless numbers of reddish ceramic sherds that literally cover the ground (Figs. 5, 6). It is not surprising, therefore, that the first attempt at dating Predynastic sites in Egypt was based upon typological (shape, colour and decoration) classification of ceramic wares.
Petrie (1920) introduced the method called "sequence dating" by classifying ceramic wares into eight different classes on the basis of their frequencies at 900 graves. Cultural subdivisions were designated using the sequence dating and were named after the Predynastic sites at which the pottery was first described. Five types of ceramic styles are generally recognized from the Predynastic period: straw tempered ware, plum red ware, marl ware, grit ware and rippled ware (Fig. 7). With the exception of the first type, production of these different ceramic styles was drastically reduced by the beginning of the Pharaonic period, and they were generally succeeded by a hard orange ware. Straw tempered ware and plum red ware (i.e., the red wares) are the major types of ceramic artifacts present at Hierakonpolis.

In order to probe the evolution of eeramic technology from the Predynastic to the "Protodynastic" period, the raw materials used for manufacturing the different types of ceramics were first investigated. On the assumption that ceramic pottery produced in a particular area would carry a specific chemical fingerprint related to the unique chemical properties of the raw materials, trace element analysis was carried out using Neutron Activation Analysis (NAA) and Scanning Electron Microscopy (SEM). Results indicated that while ceramic styles changed during the Predynastic to Protodynastic time period, the clay sources remained the same. They also showed that the Nile sediments were first processed to remove coarser fragments before being used as a pottery paste, though this separation was less thorough for the grit and straw tempered ware than for the plum red ware.

In making ceramies, the mineralogy and the chemical composition of the raw materials - the baking paste - significantly affect the optimum conditions required for welding the grains together and for the development of the vitrification structure. For example, when $\mathrm{Ca}$ salts are added to clay, vitrification oceurs slowly in the 800 to $850^{\circ} \mathrm{C}$ temperature range, but above this temperature a definite glass

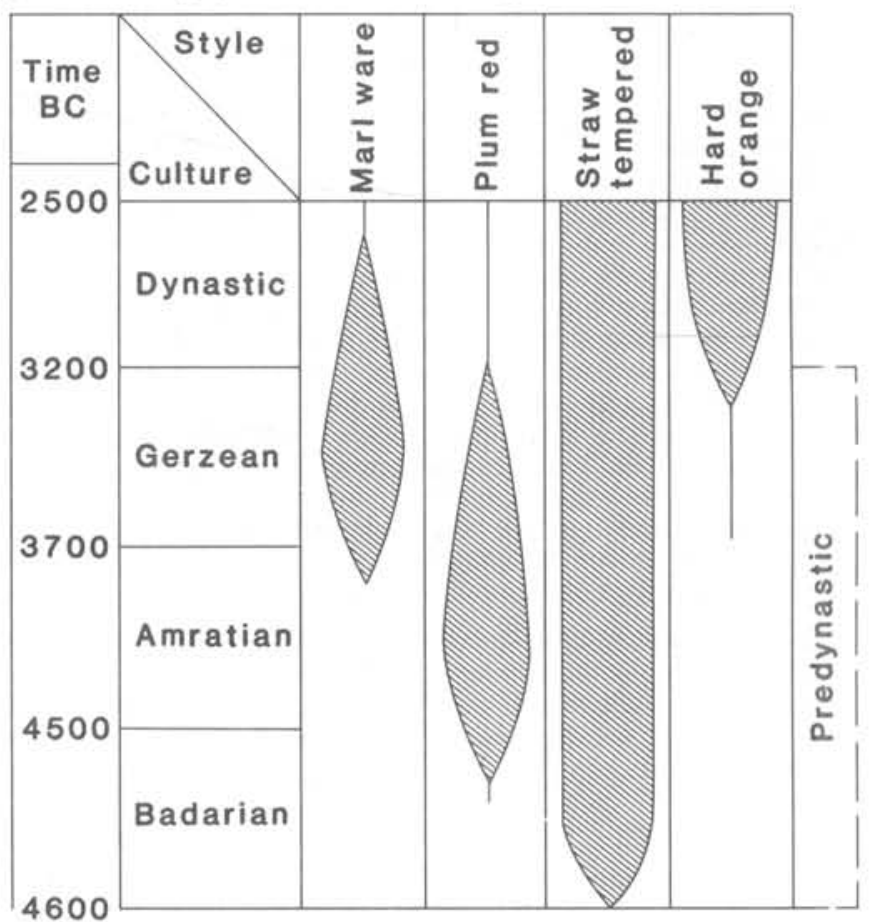

Figure 7: Abundance and time spans of the different ceramic styles during the Predynastic period. 
phase appears rapidly (Maggetti, 1982; Nagetti et al., 1984). Thus, studies of the microstructures developed during firing, the $\mathrm{Ca}$ abundance in the ceramic samples relative to the raw materials, and the mineralogical changes that take place during the firing processes should enhance our understanding of the manufacturing techniques and the accompanying firing temperatures.

Several ceramic samples of straw tempered ware, plum red ware, hard orange ware and marl ware were analyzed by NAA and with an SEM assembled with an energy dispersive $\mathrm{X}$-ray system. The Ca concentrations found in the various ceramic types and in their expected raw materials were high $(12 \%)$ in the orange ware relative to both the Predynastic wares and the Nilotic sediments $(1.4-4 \%)$ used for their production. This clearly indicates that the baking paste of the hard orange ware was very different from that involved in making the Predynastic wares. Moreover, the differences are too great to assume that the hard orange ware was only made from Nile sediments. The older shale deposits from the Great Wadi are characterized by a high percentage of $\mathrm{CaSO}_{4}$ and $\mathrm{CaCO}_{3}$ and these may have been mixed with some Nile silts to form the baking paste of the hard orange ware.

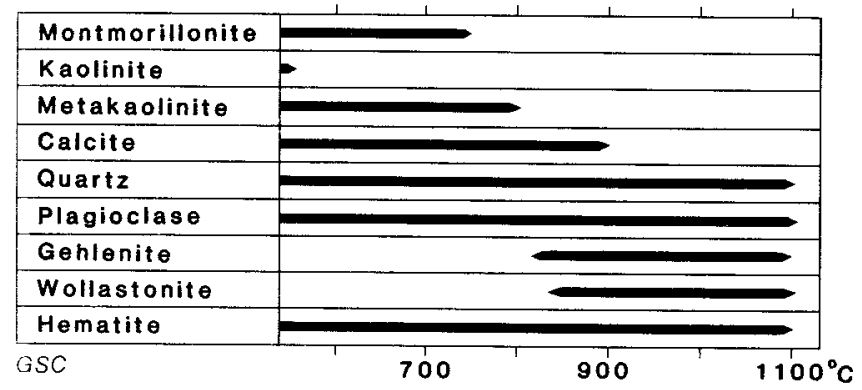

Figure 8: Diagram showing the mineralogical changes during firing.

The presumed raw materials for the Egyptian ceramics consist mainly of montmorillonite $\left(\mathrm{Al}_{2} \mathrm{O}_{3} \cdot 4 \mathrm{SiO}_{2} \cdot \mathrm{H}_{2} \mathrm{O}\right)$ with some kaolinite $\left(\mathrm{Al}_{2} \mathrm{O}_{3} \cdot 2 \mathrm{SiO}_{2} \cdot 2 \mathrm{H}_{2} \mathrm{O}\right)$, according to Hassan et al. (1976). Measurements of the different mineral phases that make up the ceramic potteries can give valuable information on the chemical and mineralogical changes that occurred during the firing of the ceramics. The $X$-ray powder diffraction method was used to determine the mineral composition of several ceramic sherds from Hierakonpolis, and this was compared with the thermal stabilities for the different types of minerals (Fig. 8). It was clear that the firing temperatures for all of the ceramic samples studied exceeded $750^{\circ} \mathrm{C}$, because montmorillonite, which is present in all the baking pastes of Egyptian ceramies but never in the fired ceramics, starts to dehydroxylate at about $500^{\circ} \mathrm{C}$ and is complete by $750^{\circ} \mathrm{C}$.

$\mathrm{X}$-ray analysis of the marl wares showed anorthite diffraction lines without any sign of spikes. This clearly indicates that anorthite was formed from the reaction of kaolinite and calcite, most probably according to the following equation:

$\left(750-850^{\circ} \mathrm{C}\right)$

$\mathrm{Al}_{2} \mathrm{O}_{3} \cdot 2 \mathrm{SiO}_{2} \cdot 2 \mathrm{H}_{2} \mathrm{O}+\mathrm{CaCO}_{3}-2 \mathrm{H}_{2} \mathrm{O}+\mathrm{CaAl}_{2} \mathrm{Si}_{2} \mathrm{O}_{8}+\mathrm{CO}_{2}$

According to this $\mathrm{H}_{2} \mathrm{O}$ vapor and $\mathrm{CO}_{2}$ would have been liberated and this would have left relicts of bubbling on the surface of the new anorthitic phase. This, indeed, was the case in all of the marl ware samples examined under the SEM.

This reaction may also have taken place during manufacture of the orange ware, but it is difficult to prove that anorthite is the predominant plagioclase mineral here because of the presence in the raw material of albite, which gives almost identical diffraction lines. However, the occurrence of gehlenite $\left(\mathrm{Ca}_{2} \mathrm{Al}_{2} \mathrm{SiO}_{7}\right)$ in the hard orange ware indicates that it was formed from heating clay minerals and calcite together, because gehlenite is not a common mineral in the Nilotic sediments or in the shale deposits.

The fact that calcite is in the marl ware and the orange ware samples indicates, moreover, that the firing temperature did not exceed $900^{\circ} \mathrm{C}$. The absence of montmorillonite, kaolinite and calcite, and the presence of metakaolinite in some ceramic samples suggests that their firing temperatures, and most probably those for all ceramic types, were in the 800 to $900^{\circ} \mathrm{C}$ range. It is likely, therefore, that the basic differences among the various types of ceramics are not due to firing temperature but rather to contrasts in the baking paste used as well as the amount of time and effort spent in kneading the raw materials into the baking paste.

Thus it seems that the ancient Egyptian craftsmen had a choice of raw material from the different types of sediments. They also observed the different quality and colour produced from firing marl (such as the Pliocene marine sediments north of Luxor) as contrasted with the Nilotic sediments (i.e., the marl ware ceramics). They realized that firing of marl sediments did not produce the attractive red colour but produced a type of ceramic whose surface was easier to decorate. For example, this type of ceramic was produced in Nagada and Ballas, north of Luxor (Fig. 1).

The firing of both types of sediments (i.e., Nile silt and marl) seems to have increased the ancient craftsman's knowledge of ceramic technology. This knowledge and experience of manufacturing the two types of red ware (i.e., straw tempered and plum red) and the marl ware probably allowed the Predynastic people to produce another type of pottery by adding or mixing Ca-rich sediments to the Nilotic clay to produce the hard orange ware. This new ware seems to have been quite pleasant, for it has the attractive reddish colour as well as the smooth surface that is easy to decorate. Thus Egyptian craftsmen continued to produce it for more than 4000 years after the Predynastic period.

Perhaps the most significant conclusion from this study of the evolution of ceramic technology from the Predynastic to Protodynastic period is that Egypt then was not a society bound by tradition. The Predynastic people were innovative and willing to experiment with new methods for ceramic production. This innovative ability continued to the extent that within two to three centuries they were able to establish the first nation state in human history. While much still remains to be learned, it is clear that geoarchaeology and geochemistry can help anthropologists to scientifically study and understand our past.

\section{Acknowledgements}

I wish to thank especially Dr. Nichael Hoffman, Director of the Hierakonpolis expeditions, for giving me the opportunity to participate in his archaeological expeditions in 1980 and 1984. Professor Dr. Richard Mitchell performed the X-ray diffraction experiments and provided mineralogical insights. Neutron activation analysis was made posBenneche. I am grateful to Dr. Hoffman and iv. Trad for the use of their photo of Finally, I wish to express my deepest gratitude and apprecistion to Prot. pro brapy Issawi for his continuous help, encouragement andice, and for his useful criticisy th reviewing this paper.

Dr. H. Hamroush is a geochemist at the Department of Geology, Cairo University, (Giza, Egypt). Much of the work reported here was undertaken during his recent Ph.D. studies in analytical geochemistry at the University of Virginia, U.S.A. Dr. Hamroush is interested in archaeological sediments and ceramic artifacts as well as the geochemical behavior of trace elements in Nile sediments.

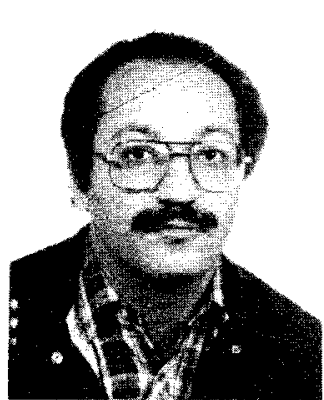




\section{References}

Allen, R., Hamroush, H., Nagle, C. and Fitzhugh, W., 1984. Use of Rare Earth Element analysis to study the utilization and procurement of soapstone along the Labrador coast. In: Archaeological Chemistry - III, J.B. Lambert (ed.). American Chemical Society, washington, D.C., p. 3-18.

Baker, B.11., Nohr, P.A. and Williams, L.A.J., 1972. Geology of the eastern rift system of Africa. The Geological Society of America Special Paper No. 136, 67p.

Butzer, K.W., 1960. Achaeology and geology in ancient Egypt. Science, v. 132, no. 3440, p. 1617-1624.

Butzer, K.W., 197l. Environment and Archaeology: An Ecological Approach to Prehistory, 2nd ed. Adline-Atherton, Chicago, p. 703.

Butzer, K.W. and Hansen, C.L., 1968. Desert and River in Nubia: Geomorphology and Prehistoric Environments at the Aswan Reservoir. University of Wisconsin Press, Madison, Wisconsin, p. 1-562.

Cerling, T.E., Brown, F.H., Cerling, B.W. et al., 1979. Preliminary correlations between the Koobi Fora and Shungura formations, East Africa. Nature, v. 279, no. 57ug, p. $118-121$.

Cerling, T.E., Hay, R.L. and O'Neil, J.R., l977a. Isotopic evidence for dramatic climatic changes in East Africa during the Pleistocene. Nature, v. 267, no. 5607, p. 137-138.

Cerling, T.E. and Powers, D.W., 1977. Palaeorifting between the Gregory and Ethiopian rifts. Geology, v. 5, no. 7, p. $441-444$

Fairbridge, R.W., (ed.), 1972. The Encyclopedia of Geochemistry and Environmental Sciences. Van Nostrand Reinhold Co., New York, p. 1-1321.

Gladfelter, B.G., 1977. Geoarchaeology: the geomorphologist and archaeology. American Antiquity, v. 42, no. 4, p. $519-538$

Hamroush, H., 1980. Geological and Geoarchaeological studies between Qena and Luxor (Nagada-Khattara) Upper Egypt. Niasters of Science Thesis, Cairo University.

Hamroush, H., 1982. A preliminary report on the Quaternary geology and geoarchaeology of Hierakonpolis. In: The Predynastic of Hierakonpolis. Alden: Oxford, London, p. 93-101.

Hamroush, H., 1985. Archaeological geochemistry of Hierakonpolis in the Nile valley, Egypt. Ph.D. Dissertation, University of Virginia.

Hassan, F.A., 1976a. Heavy mineral analysis of some Pleistocene sediments in the Nile Valley. Appendix D. In: Prehistory of the Nile valley, F. Wendorf and R. Schild (eds.). Academic Press, New York, p. 331-338.

Hassan, F.A., 1976b. Heavy minerals and the evolution of the Modern Nile. Quaternary Research, v. 6, no. 3, p. 425-444.

Hassan, F.A., 1978. Sediments in archaeology: methods and implications for palaeoenvironmental and cultural analysis. Journal of Field Archaeology 5, p. 197-213.

Hassan, F.A., 1980. Prehistoric settlements along the main Nile. In: The Sahara and the Nile, N. Williams and H. Faure (eds.). A.A.Balkema, Rotterdam, p. 421-450.

Hassan, F.A., Attia, A.K., Wendorf, F., Schild, K. and Issawi, B., 1976. X-ray mineralogy of some Quaternary Nile sediments. In: Prehistory of the Nile Valley, F. Wendorf and R. Schild (eds.). Academic Press, New York, p. 339-342.

Heinzelin, J. de, 1968. Geological history of the Nile Valley. In: The Prehistory of Nubia, v. 1, F. Wendorf, (ed.). Southern Methodist University Press, Dallas, p. 19-55.
Henderson, P., 1982. Inorganic Geochemistry. Pergamon Press, Oxford, New York, p. 1-353.

llenderson, P., 1984. General geochemical properties and abundances of the rare earth elements. In: Rare Earth Element Geochemistry, P. Henderson (ed.). Elsevie:, Amsterdam, p. 1-32.

Hoffman, W.A., 1979. Egypt before the Pharaohs. Knopt Press, New York. $39 \mathrm{lp}$.

Hoffman, H.A., 1982. The Predynastic of Hierakonpolis - an interim report. Egyptian Studies Association Publ. No. 1., Cairo Univ. Herbarium and Department of Sociology and Anthropology, Western Illinois Univ.

Issawi, B., 1983. Ancient rivers of the eastern Egyptian desert. Episodes, v. 6, no. 2, p. 3-6.

Kholief, M.N., Hilmy, E. and Shahat, A., 1969. Geologic 1 and mineralogical studies of some sand deposits in the Nile Delta. U.A.R. Journal of Sedimentary Petrology, v. 3!, no. 4, p. 1520-1529.

Maggetti, M., 1982. Phase analysis and signifieance tor technology and origin. In: Archaeological ceramics. Smithsonian Institution Press, Washington, D.C., p. 121-133.

Vaggetti, M., Westley, H., and Olin, J.S., 1984. Provenance and technical studies of Mexican Majolica using elemental and phase analysis. In: Archaeological Chemistry - II. American Chemical Society, Washington, D.C., p. 151-191.

Nicholson, S.E., 1980. Saharan climates in historic times. In: The Sahara and the Nile. Quaternary Environments and Prehistoric Occupation in Northern Africa, M.A.J. Williams and H. Faure (eds.). A.A. Balkema, Rotterdam, p. 173-200.

Nilsson, T., 1983. The Pleistocene: Geology and Life in the Quaternary Ice Age. D. Reidel Publishing Company, U.S.A., London, England, $65 \mathrm{lp}$.

Petit-Maire, N., 1986. Palaeoclimates in the Sahara of vali. Episodes, v. 9, no. 1, p. 7-15.

Petrie, W.M.F., 1920. Prehistoric Egypt. British School oi Archaeology in Egypt. London, p. 1-25.

Said, R., 1981. The Geological Evolution of the River Nile. Springer Verlag, New York, Heidelberg, Berlin, $151 \mathrm{p}$.

Shukri, N.M., 1950. The mineralogy of some Nile sediments. Quarterly Journal of the Geological Society, London, v. 105, pt. 4 , p. $511-534$; v. 106 , pt. 4, p. 466-467.

Shukri, N.Ml., 1951. Wineral analysis tables of some Nile sediments. Bulletin of the Institute Desert, Heliopolis. Tome 1, no. 2, p. 39-67.

Stheeman, H.A., 1932. The geology of southwestern Ugandid with special reference to the stanniferous deposits. Martinus Nijhof, The Hague, 144p.

Vermeersch, P.vl., 1970. L'Elkabian une Novelle Industrie Epipaléolithique d'Egypte. Chronique d'Egypte, v. 45, p. 45-67.

Wendorf, F. and Schild, R., 1976. Prehistory of the Nile Valley. Academic Press, New York, 404p. 